\title{
A Critical Evaluation of the Psychological Contract as a Determiner of Behaviour in Organisations
}

\author{
Marius Sebastian Rücker \\ University of Hertfordshire, UK
}

Received: Dec. 4, 2017 Accepted: Dec. 27, $2017 \quad$ Online published: Jan. 2, 2018

doi:10.5296/ijhrs.v8i1.12403ＵRL: https://doi.org/10.5296/ijhrs.v8i1.12403

\begin{abstract}
Due to a perpetual increase in globalisation, it has become more significant to hire employees who believe in the corporate mission and values and to incentivise these employees to help the organisation to grow. This leads to the question whether and to which extent organisations can determine the behaviour of employees. One widely known concept of measuring and predicting the psychological satisfaction of members of an organisation is the psychological contract. Therefore, the aim of this research paper is to evaluate the psychological contract as a determiner of behaviour in organisations. In order to conduct this evaluation, different stages of the relationship between employees and organisations are examined. The evaluation of the psychological contract in regards to these different stages has led to the result that the psychological contract determines organisational behaviour though external influences and through internal communication of an organisation. In addition to that, the critical evaluation has shown that the psychological contract continues to be a field of interest in organisations in the future and for prospective examinations.
\end{abstract}

Keywords: organizational psychology, psychological contract, behavior

\section{Introduction}

Since Frederick Winslow Taylor introduced the theory of scientific management as an essential element of industrialisation, organisational behaviour has changed significantly. The behaviour in organisations developed from a segmented perception of workforce and management into a more individual based humanistic point of view. Another considerable source of alteration is the progression into a globalized expansion of businesses. The individual gains significance, also in terms of cultural expertise. Each individual contributes to an organisation by allocating his or her knowledge, experience and talents. Professional organisations have realised that in order to unfold their potential, employees have expectations towards the organisation they work for. Expectations, obligations and promises between both parties determine the behaviour in organisations. This interchange between 
employees and organisations occurs in a mutual way (Rousseau, 1990). In order to develop this mutual interference into productivity and efficiency, organisations need to address the requirements and prospects of their employees. In addition to a written and signed contract, an unwritten contract takes effect. This contract is termed 'psychological contract' (George, 2009). This concept of a psychological contract traces back to ancient philosophers and their consideration of a social contract. In early management theory, the influence of interchange between employees and organisations was examined, which led to the understanding of unwritten obligations between both interactants. The conception of the 'psychological work contract' defined by Rousseau (Rousseau, 1990) provides an introduction to the topic. In the further course of development, the idea of determining behaviour in organisations became more important (Roehling, 1997). This research paper is concerned with the question of whether if and to what extent the psychological contract determines behaviour in organisations and how this determination is recognizable. After defining the major terms, the determining power of the psychological contract in different stages of the relationship between employees and organisations is examined. This analysis addresses the pre-employment phase until the phase of an employee leaving the company due to breach and violation of the psychological contract. Furthermore, the utility of this concept is investigated and a future outlook of the psychological contract as a determiner of organisational behaviour is given.

\section{The Psychological Contract and Organisational Behaviour}

In order to examine the determining power of the psychological contract on organisational behaviour, a definition of both terms is utilitarian. Organisational behaviour addresses the conception of the behaviour of human beings in organisational settings (Mullins, 2007). This study includes individual as well as group behaviour. The aim of this field of study is to ameliorate organisational performance and efficiency (Baruch, 2002). The psychological contract, as an implied concept that is promise based before associating with an organisation, is defined by reciprocal expectations of employees and organisations. Its apparentness mostly emerges in case of a breach of this unwritten contract. Moreover, the psychological contract can be seen as an assurance of mutual utility, due to fulfilment of the respective expectations of both parties (George, 2009). The psychological contract can be divided into a transactional and relational aspect. Monetary and economic obligations, such as warrantable payment, define the transactional psychological contract (Baruch, 2002). The relational psychological contract introduces a focus shift from a short-termed transaction towards the relationship between the employer and the employee. Obligations like loyalty and job security are indicative of a long-term relationship (McDonald \& Mankin, 2000). Through expectations and promises before the recruitment phase, the psychological contract determines organisational behaviour prior to the initial contact of the potential employee and the organisation. Before an employee collaborates with an organisation, social and media-collaborated influences affect the psychological contract of this person (Blades, Ferguson, \& Richardson, 2000). These experiences contribute to the development of conceptions, which results in different ideas about certain professions. For example, these ideas caused by wrong communication lead to the fact that nearly 50 per cent of professionals 
regret a career choice in the medical sector (Blades, Ferguson, \& Richardson, 2000). Even if the employee has no direct contact with the organisation in this phase, these ideas can give rise to the progression of a relational psychological contract (George, 2009). The perception of the psychological contract that is linked to these ideas determines organisational behaviour by constraining organisations to react to those ideas. In order to utilize the determining power of psychological contracts in their favour, organisations ought to inform their potential employees about the factors included in the careers they offer.

\section{The Influence of the Psychological Contract in the Pre-Employment Phase}

Through communicating the requirements and expectations of certain professional careers, organisations are able to influence the perceptions that affect a psychological contract. It is important that the communication in the pre-employment phase is congruent in its execution. Otherwise a misleading communication of the behaviour in a specific organisational setting, results in an apprehended breach of the psychological contract (Morrison, 1997). According to Morrison, incongruence is one of the major factors that leads to inconsistency between an organisation and an employee (Morrison, 1997). Admittedly, this incongruence can vary in its perceived dimension because every human being interprets information in different contexts. Specific schemata of a person have various influences of this perceived insecurity. Nevertheless, precise communication intensifies congruence (Morrison, 1997). Robinson supports this statement by claiming, that employees who are provided with a realistic preview of their future position, experience an increase in congruency (Robinson, 2000).

\section{The Influence of the Psychological Contract in the Recruitment Phase}

During the recruitment and selection phase, the psychological contract influenced through external factors, develops to an actual determiner of future behaviour in an organisation. At this stage the psychological contract occurs in form of expected obligations towards a specific organisation that the employee applies to. The recruitment and selection of an employee portrays the transition between the emergences of the psychological contract towards experiencing the psychological contract as a determiner of behaviour in the early stage of the employment phase. Shore \& Tetrick argue that this development implicates communications and encounters with various representatives of a certain organisation. As a result of that, different messages, non-verbal as well as verbal are sent (Shore \& Tetrick, 1994).

Those different messages lead to various understandings of the psychological contract and thence the intensity or direction of the determination of organisational behaviour can vary. Job interviews can serve as an example. By communicating with an interviewer of an organisation, his or her values, perceptions and understandings of appropriate and correct behaviour in the organisation transfer to the interviewee. This transpires consciously by communicating the expected behaviour verbally or unconsciously by representing the anticipated behaviour in a non-verbal manner. Consequently, the recruitment phase implies the endangerment of inaccurate communication of the expected psychological contract. This can be supported by Shore \& Tetrick, who claim that the progression of the psychological contract is a consequence of interactions between the environment in organisations and 
individuals (Shore \& Tetrick, 1994).

One method to prevent the danger of an inaccurate communication of the psychological contract is to implement realistic job previews. This method is mainly used in the early stages of recruitment. It provides an applicant with positive and negative facets of the job (Sims, 1994). Due to the presentation of realistic conditions, organisations try to accurately communicate the presupposed psychological contract. The fact that a realistic communication of the psychological contract in the recruitment process determines behaviour in organisations is supported by Breaugh \& Billings (Breaugh \& Billings, 1988). A comparison of employees hired with realistic and unrealistic expectations of the psychological contract shows that realistic job previews lead to turnover reduction, increased contentment and involvement (Breaugh \& Billings, 1988). This indicates that the psychological contract implicated in the recruitment phase, influences the determination of behaviour in organisations with regard to the employer/employee relationship.

\section{The Influence of the Psychological Contract in the Employment Relationship Phase}

The employment relationship reveals the scale, in which the pre-employment phase and the recruitment and selection phase influence behaviour in organisations, through communicating the psychological contract. In this timeframe the already anticipated and the indeed experienced psychological contract interface. In contradistinction to the antecedent phases, the employment relationship phase is characterized by an attenuation of information seeking and an active interchange of assurances. This interchange can occur intermittently (George, 2009). A periodical exchange of information about target compliance between an employee and a manager can serve as an example. The bilateral understood and experienced psychological contract already determined the behaviour in the organisation. In this phase the psychological contract is established. Although employees regard performance management critically, George argues, that management development affects a psychological contract. This assertion substantiates the concept, that organisational behaviour during the employment relationship is still modifiable, by influencing the psychological contract (George, 2009).

During the employment relationship the relational aspects tend to be more influential in terms of organisational behaviour, than the transactional factors. The transactional determinants, including monetarist factors, are already established through communicating them before and in the early stages of the employment relationship. Relational aspects, such as loyalty and commitment to an organisation, anticipated job security or job insecurity and the disposition of a continuing relationship with an organisation, are still suggestible in this phase (Cavanaugh, 1999). Cavanaugh \& Noe state that the willingness to stay in an organisation is considerably influenced by the intensity of compliance respecting relational aspects of the psychological contract. According to Coyle-Shapiro the attributed importance of a certain commitment of an employee influences the behaviour in association with the psychological contract (Coyle-Shapiro, 2002). From this it follows that a high attachment to relational obligations affects the behaviour of employees in organisations in a positive way (Coyle-Shapiro, 2002). This conclusion supports the statement that relational aspects of the psychological contract as determiners of organisational behaviour can change in the 
employment phase. This happens mainly through the assigned value to relational obligations.

\section{Effects of a Breach and Violation of the Psychological Contract}

The psychological contract is not only a determiner of behaviour in organisations before and during the employment relationship, but also in the phase of its ending. One of the most pervasive occasions for ending the professional relationship between an organisation and an individual employee is a breach or a violation of the psychological contract. Morrison defines a breach of a psychological contract as a perception of an individually apprehended non-compliance of obligations (Morrison, 1997). This failure of obligations is in direct proportion to the perceived input an individual thinks, he or she contributed to the organisation. Contract violation is defined as an implication that appears as a result of an individually perceived breach of a psychological contract (Morrison, 1997). The violation involves a shift in the emotional condition associated with the psychological contract. A contract breach and a consequent violation can emanate from both representatives of the psychological contract. On the one hand, the perceived breach from the organisation can for example be caused by unexpected downsizing or outsourcing. On the other hand, unfulfilled promises on the part of the employee can lead to a breach and a resulting violation of the psychological contract. This is supported by Robinson and Rousseau who claim that both representatives can be responsible for a breach (16).

Furthermore, a difference in perception of breach and violation is recognizable by comparing supervisors and subordinates within an organisation. Managers and their employees differ in contemplating the justification of a psychological contract breach. It can be argued that a supervisor has a higher commitment and loyalty to an organisation. Managers for example are provided with their goals and target compliance directly from the representative of the organisation, whereas employees are faced with further hierarchy levels. Therefore, supervisors can identify themselves more with the organisation. The result of this identification is a diminished accusation for breaching the psychological contract. This pronouncement is supported by Lester, who claims that subordinates regard breach as intentionally elicited by an organisation (Lester, 2002). As opposed to this, supervisors associate the origination of a contract breach with external influences, uncontrollable by the organisation (Lester, 2002).

Breach and violation can cause different emotional reactions, such as frustration, disappointment and anger. An imputation of intention intensifies the accompanied emotions of a psychological contract violation (Morrison, 1997). Attitudes and behaviours regarding the execution of work modify during contract violation (George, 2009). For example, commitment develops into negative intentions and the volition to stay shifts towards the intent to leave the organisation. A model that describes the changes in working behaviour is the exit-voice-loyalty-neglect model. This model is engendered in the organisational behaviour theory. The model illustrates the most pervasive behavioural consequences in organisations that are determined by breach and violation of the psychological contract. Behavioural consequences such as the desire to exit the organisation, to voice discontent, declining loyalty, neglecting liabilities and to react with aggression affect organisations 
negatively (George, 2009). It can be discerned that the psychological contract is not only a positive determiner of organisational behaviour. In case of breach and violation it can also be a negative determining factor.

After having examined the determining power of the psychological contract in terms of behaviour in organisations from the pre-employment phase up to the end of the employment relationship through breach or violation, the utility of this concept is investigated. The concept of the psychological contract fulfils its measurable aim in a subjective way. Therefore, the face validity is highly developed. Despite high face validity it can be criticised that an accordance concerning the definitions is missing. Different descriptive terms are used to describe the components of this concept (18). A consistent definition of the psychological contract is missing. Guest also claims that the psychological contract is not a measure or theory, but rather a constructive framework (Guest, 1998). This complicates an evaluation of this psychological concept. Even if a form of evaluation is implemented, it is questionable at which point of an employment relationship the psychological contract is in existence. Furthermore, it is debatable, whether a valid employment relationship is indispensable in order to be committed to an organisation (George, 2009). To exemplify this it can be mentioned that proponents of certain products and organisations feature similar behavioural patterns, as individuals who are in an employment relationship with the particular organisation.

The aspect of breach and violation can also be seen critically. The psychological contract does not distinguish itself from other concepts related to interchange in the employment relationship (Coyle-Shapiro, 2000). Due to the intersection between the concept of the psychological contract and other theories that conclude that social exchange eventuates in certain behaviour, the additional value is questionable (Guest, 1998). Moreover, the main aspect of current research examines the conception of contract violation that emanates from organisations. Less is investigated in terms of contract violation by employees (Guest, 1998).

\section{Results and Discussion}

Notwithstanding the criticism, the psychological contract continues to be a field of interest in organisations in the future and for prospective examinations (George, 2009). Therefore, its determining power of organisational behaviour requires examination. According to Baruch, an emergence of new types of relationships between individuals and organisations lead to new forms of involvement (6). The prospective emphasis on the altering dynamic of the psychological contract theory is supported by Anderson \& Schalk by claiming that the alteration of psychological contracts will be a main future research topic (Anderson \& Schalk, 1998). Regarding this, the psychological contract is still an area that needs further investigation. Whereas Anderson \& Schalk see future examination in conceptualizing and measuring the psychological contract, George misses a deficiency of personality research (George, 2009).

In terms of future outlook, there is also a lack of research about gender and age differences. Furthermore, a future focus on research can be the compliance of this unwritten contract, rather than the breach and accompanied violation. In terms of its determining power of 
organisational behaviour it is still unclear up to what extent the culture of an organisation includes psychological contracts of employees as components. Moreover, examining behaviour that is linked to careers of individual employees could be a future research area. In addition to that future research provides an opportunity to connect the psychological contract theory with other fields of psychological research. George mentions a possible connection with positive psychology (George, 2009). Despite the fact that the psychological contract remains a determining factor of behaviour in organisations, the future of the concept is unpredictable and complex.

\section{Conclusion}

In conclusion, it is perceptible that the psychological contract is a powerful determiner of behaviour in organisations throughout all phases of the employment relationship. This unwritten contract determines organisational behaviour though external influences and through internal communication of an organisation. It can be specified that the determining aspects can be both positive for organisational behaviour through fulfilment of the psychological contact and negative through contract breach and violation. In terms of utility of the psychological contract opinions are divided, whereby different aspects are criticised. Future research is required to examine different areas and influences of the psychological contract that experienced a paucity of investigation.

\section{References}

Anderson, N., \& Schalk, R. (1998). The Psychological Contract in Retrospect and Prospect. $\begin{array}{llll}\text { Journal of } \quad \text { Organizational } & \text { Behavior, } & \text { 637-647. }\end{array}$ https://doi.org/10.1002/(SICI)1099-1379(1998)19:1+<637::AID-JOB986>3.0.CO;2-H

Baruch, Y. (2002). Multiple Commitments: A Conceptual Framework and Empirical Investigation in a Community Health Service Trust. British Journal of Management, 13(4), 337-357. https://doi.org/10.1111/1467-8551.00250

Blades. D. D., Ferguson, G., \& Richardson, H. C. (2000). A study of junior doctors to investigate the factors that influence career decisions. British Journal of General Practice, 50(455), 483.

Breaugh, J. A., \& Billings, R. S. (1988). The realistic job preview: Five key elements and their importance for research and practice. Journal of Business and Psychology, 2(4), 291-305. https://doi.org/10.1007/BF01013761

Cavanaugh, M. A. (1999). Antecedents and consequences of relational components of the new psychological contract. Journal of Organizational Behavior, 20(3), 323-340. https://doi.org/10.1002/(SICI)1099-1379(199905)20:3<323::AID-JOB901>3.0.CO;2-M

Coyle, S. J. (2000). Consequences of the psychological contract for the employment relationship: A large scale survey. Journal of Management Studies, 37(7), 903-930. https://doi.org/10.1111/1467-6486.00210

Coyle, S. J. (2002). A psychological contract perspective on organizational citizenship 
behavior. Journal of Organizational Behavior, 23(8), 927-946. https://doi.org/10.1002/job.173

David, J., McDonald, P., \& Makin, J. (2000). The psychological contract, organisational commitment and job satisfaction of temporary staff. Leadership \& Organization Development Journal, 21(2), 84 - 91. https://doi.org/10.1108/01437730010318174

George, C. (2009). The Psychological Contract: Managing and developing professional groups. Berkshire: Open University Press.

Guest, D. E. (1998). Is the psychological contract worth taking seriously?. Journal of Organizational Behavior, 19(1), 649.

https://doi.org/10.1002/(SICI)1099-1379(1998)19:1+<649::AID-JOB970>3.0.CO;2-T

Lester, S. W. (2002). Not seeing eye to eye: differences in supervisor and subordinate perceptions of and attributions for psychological contract breach. Journal of Organizational Behavior, 23(1), 39-56. https://doi.org/10.1002/job.126

Morrison, E. W. (1997). When employees feel betrayed: a model of how psychological contract violation develops. The Academy of Management Review, 22(1), 226-256.

Mullins, L. J. (2007). Management and Organisational Behaviour. $8^{\text {th }}$ edn. Harlow: Financial times Prentice Hall.

Robinson, S. L. (2000). The development of psychological contract breach and violation: a longitudinal study. Journal of Organizational Behavior, 21(5), 525-546. https://doi.org/10.1002/1099-1379(200008)21:5<525::AID-JOB40>3.0.CO;2-T

Robinson, S. L., \& Rousseau D. M. (1994). Violating the psychological contract: Not the exception but the norm. Journal of Organizational Behavior, 15(3), 245-259. https://doi.org/10.1002/job.4030150306

Roehling, M. V. (1997). The origins and early development of the psychological contract construct. Journal of Management History, 3(2), 204-217. https://doi.org/10.1108/13552529710171993

Rousseau, D. M. (1990). New hire perceptions of their own and their employer's obligations: A study of psychological contracts. Journal of Organizational Behavior, 11(5), 389-400. https://doi.org/10.1002/job.4030110506

Shore, L., \& Tetrick, L. E. (1994). The psychological contract as an explanatory framework in the employment relationship. Trends in Organisational Behavior, 1, 91-109.

Sims, R. R. (1994). Human resource management's role in clarifying the new psychological contract. Human Resource Management, 33(3), 373-382. https://doi.org/10.1002/hrm.3930330306 


\section{Copyright Disclaimer}

Copyright for this article is retained by the author(s), with first publication rights granted to the journal.

This is an open-access article distributed under the terms and conditions of the Creative Commons Attribution license (http://creativecommons.org/licenses/by/4.0/). 